\title{
A Perception into Food Image and Revisit Intention for Local Cuisine from Foreign Tourist Perspective - The Case of Ho Chi Minh City - Vietnam
}

\author{
Hsin Kuang Chi, Kuo Chung Huang, and Bich Dao Thi Nguyen
}

\begin{abstract}
In culinary tourism, the perception into destination food image is the most important component for destination marketing plan. Therefore, the quanlitative method was applied to confirm role of destination food image in Vietnam by analyze the tourist's opinion on TripAdvisor. Moreover, to understand new insights into tourist behavior in the destination choice, the qualitative method explore the bidirectional causal relationship between the destination food image and perceived value that eventually contributes to revisit intention. The findings contribute to identify destination image theory value in tourism research, especially in the context of tourists' local food experiences. Finally, this study provides insight into how to built destination food image, especially cognitive food image is extremely crucial and necessary when Vietnam intend to build an attractive food destination that perceived by tourist as well as the development of marketing strategies for culinary tourism in Vietnam.
\end{abstract}

Index Terms - Food image; Preference; Customer perceived value; Customer satisfaction; Revisit intention.

\section{INTRODUCTION}

According to [36], food image about local cuisine is increasingly used in the marketing of a tourism destination. Based on these perspectives, it can be argued that local cuisine is an important element that can add value to a destination [11], and furthermore may contribute to the sustainable competitiveness of a tourism destination [45].

Most tourists want to try different food when they travel to a new place. In other words, culinary experience becomes an increasingly important aspect of the travel experience and a vital destinations choice factor for tourists [9]. The uniqueness of local cuisine can significantly enhance a destination's image, as [26] pointed out that tourists often place considerable emphasis on how they feel at a destination, and how they experience what the destination offers, by carefully selecting that special food that might fulfill a particular personal desire. In addition, the relationship between food and a tourist destination is inevitably related with each other, as a destination provides food as a product of tourist attraction. Once tourists are satisfied with foods offered, local foods could serve as an attraction for tourists to return to the same destination [2].

Base on annual statistics of Tourism Bureau in 2017, the most impressions evaluated by foreign tourists were the following: the cuisine (49\%) and the friendly people (40\%). Therefore, local cuisine was an important factor in travel intentions of foreign tourists. With the increasing interest in local cuisine in Vietnam, culinary tourism has been recognized as an effective promotional tool, and it is becoming a vital part of the destination [4].

Vietnam also has some convenience factors in the development of local cuisine. For instance, in "The 10 healthiest ethnic cuisines" -cnn.com, [36] pointed out that Vietnamese food is made from herbs, vegetables and fresh seafood. On the other hand, cooking techniques use water instead of oil. With the balance between meats, fresh vegetable and a selective use of spices to create a fine taste, Vietnamese food is one of the healthiest cuisines worldwide. These are some of the standout qualities of Vietnamese food. Three Vietnamese restaurants were voted in the 101 Best Restaurants in Asia 2013 on The Daily Meal- United States food website that promote the development of the restaurant industry of Vietnam nowadays. Few researchers have integrated relevant constructs into the comprehensive framework in culinary tourism. Based on the analyses of advantage in culinary tourism development, a model to understand how tourists' perception of a destination's food image can influence their evaluation of the food experience and their behavioral intentions has should be investigated [25]. Therefore, the purpose of this study is to discuss the role of food destination image into revisit intention. The study wants to emphasize the value of local cuisine to tourists as well as development and marketing destination tourism product in Ho Chi Minh City-Vietnam.

The development of comunication and information technologies and has radically changed the marketing role in tourism. For examples, they want to know how to find the tourism information easily as well as choose an exciting destination for their journey. The media network has an important key that can promote the tourism marketing activities of a country. According to statistic of Travel and Leisure magazine 2017, Trip Advisor Media Network sites is chosen as Top Travel Websites by the world's most popular and largest travel community TripAdvisor ranked second in the global review website for traveler. For TripAdivsor users, they can base on online comments to get information quickly and can find useful advice when planning or preparing to attend specific tour program, or destinations, services, hotels, airline tickets (transportation), etc related to the trip. This connection will be a bridge to provide to visitors the necessary information, travel advice, introduction of new tour programs, tour promotion, organizing competitions for tourists to building tour schedule and make the tour more practical and more attractive.

According to [44], in recent years, social media used to share information and experiences of trip such as destination, weather, environment and the other nessessary information, 
etc. On the other hand, according to marketing experts, social media content is received believe more than mass-media advertising or tourism websites [23]. Besides, the relationship between destination image and social media marketing is essencial. The goals of the study, therefore, are as follows: To summarize characteristics and demographic of traveler who comment or share their opinion on TripAdvisor and identify these comments into two factors of destination image: Affective image, Cogitive image.

\section{CONCEPTUAL BACKGROUND AND HYPOTHESES}

\section{A. Destination Image}

[34] asserts that destination image has been one of the main field of tourism research for recent years. According to [33], destination image is considered a key factor that has an important role in tourists' decision-making process. Destination image research began by [6]. On the whole, there are different between three main researchers about the definition of destination image. According to [10], destination image defined as the image as the composition of, ideas, beliefs and impressions that tourist perception about a destination. Moreover, [28] use the behavioral components to describe concept of destination image such as perceptual and cognitive. Finally, a third perspective considered as a mental impression or overall visual, experience or place (RezendeParker, Morrison \& Ismail, 2003).

In the recent studies, destination image concept is devided to two components as cognitive image and affective image [40]. Cognitive image refers to an individual's attitudes, beliefs and perceptions regarding the destination [37]. Affective image is related to the emotions and feelings of tourists toward the destination [37]. In other words, image may result of combination between cognitive and affective characteristics. Therefore, if a destination has favorable attributes, tourists will have positive impressions in their minds. One of these attributes is food. Previous studies has shown the important of food as a reason of travel intention toward the destination. [12] asserted that food is the most important element in tourists' perceptions of destination after scenery, accommodations, and climate. Local food can be a travel motivation as well as one of the main attributes of a country [4], since it supports for the local culture [29]. Despite the recognition that local cuisine is significant component in the general perception of destination image by tourists, the research discussing the elements of local cuisine from opinion of tourists are rather limited [1].

In the research of [37], the cognitive food image includes perception of tourists about smell, taste, price of product. On the other hand, the affective food image is attitude of them after using food service or product [30]. Based on previous studies, food image is evaluated by cognitive and affective elements and cognitive image has influence to effective image [7]. Especially, [34] asserted that the cognitive destination image evaluation created to the affective destination image result.

Based on reviews of the above literature, we set out the following hypothesis:

H1: Cognitive food image has influence to the affective food image

Moreover, [7] found that the relationship among cognitive image, affective image, and destination preferences. Some similar results are showed in previous hospitality studies. Especially, [39] asserted that a positive image of a particular destination influences to customer preference. Particularly, a positively preference is affected by cognitive image preference positively. On the other hand, in destination foods, Stimulus - Organization - Response $(\mathrm{S}-\mathrm{O}-\mathrm{R})$ is applied to examine how destination image effected customer preferences [8]. Similarly, some food attributes that increase of customer favorable perceptions will increase customer preference for the foods. For instance, destination food image attributes such as taste, cooking methods, safety, quality effect to customer preferences. [19] found that the healthy image of food effect to preference for food. Based on that foundation, we proposed the following hypotheses:

H2a: Food cognitive image of destination foods has a positive influence on preference for destination foods.

$H 2 b$ : Food affective image of destination foods has a positive influence on preference for destination foods.

In recent studies, the relationship between destination image and perceived value has used in tourism research area. [3] found that the experience of the customer influence on the customer perception of destination image. Moreover, when the customer feel that destination image is attracting, the customer has an overestimation of tourism destination quality. As a result, this outcome will bring the most favorable condition to destination marketing activities. In addition, when tourists are satisfied by the destination image, they have positive feeling [20]. On the other hand, individual expectations as well as customer perceived value before visit destination are reflected by destination image. From the marketing perspective, the quality of trip is based on destination satisfaction of tourist [6]. Therefore, food image including cognitive image and affective image has a direct relationship with customer perceive value [21].

H3a: Food cognitive image is positively associated with the Perceived Value

H3b: Food affective image is positively associated with the Perceived Value

Besides, based on previous research, the relationship between customer behavior and satisfaction has been examined. According to [17], destination satisfaction is considered as the main element of recommending and revisit intention of tourist. This study focused on tourists' satisfaction with their food experience in Vietnam. Some researchers believed that tourists' satisfaction with the culinary or food of a destination depends on how prior image they had about the destination's culinary compare with the real culinary experience. An empirical study by [6] stated that tourists' level of conception of the local culinary prior to consumption is likely to be less than their post-visit evaluation. [12] suggested that past eating experience and positive beliefs could prompt tourists to experience local cuisine again. If a positive culinary image is formed in tourists' mind, it will lead to tourist satisfaction, which will in turn affect tourists' behaviors. This study utilized a multidimensional, multi-attribute approach to operationalize tourists' satisfaction with their food experience in Vietnam. The term "food satisfaction" was adopted in this study for more accurate reflection of the concept and adequate differentiation from the term "tourist satisfaction". Consequently, it is vital to revisit the relationship between food image and tourist satisfaction. Therefore, the following hypothesis can be considered: 
H4a: Food cognitive image is positively associated with food satisfaction

H4b: Food affective image is positively associated with food satisfaction

H9: Food satisfaction is positively associated with revisit intention

\section{B. The relationship between perceived value, preferences, satisfaction and revisit intention of tourist in culinary tourism}

From psychology perspective, [22] asserts that destination perceived value of tourists reflect preference of them. Based on previous studies, [34] found that the relationship between the perceived value and customer preference. Especially, when a customer perceives valuable product, the customer has good impressions about destination. Consequently, it is vital to revisit the relationship between customer perceived value and their preferences.

H5: Customer perceived value has a positive effect on tourist preferences.

In the context of tourism, generally, [6] asserts that the satisfaction is key element to evaluate pre-trip expectations and post-trip experiences The satisfaction is defined as a felling or positive perception that tourists received from experiences in destination through the participation in tourism activities [6]. In this study, satisfaction includes overall satisfaction, satisfaction considering invested time and effort, and satisfaction in comparison with expectations Therefore, it is important to determine how tourists perceive the value of culinary tourism which are built on food destination images and perceived value for tourists. Moreover, both of them are related to a specific judgment of food destination and culinary products [22]. Based on previous research, the following hypothesis was proposed:

H6: Customer perceived value has a positive effect on tourist satisfaction.

Preferences is defined as evaluative judgment in the sense of liking lead to behavioral intentions [31]. Some studies have found a relationship between preferences and behavioral intention [27]. [34] confirmed a relationship between destination preferences and behavior intentions of Chinese tourists in local cuisine-related tourism destination. [5] reported that individual preference affected revisit intention positively more than the other factors. These findings indicate that customers with preferences for a famous culinary destination will consistently revisit to enjoy. Food preferences reflect individual characteristic of tourist that lead to intent to visit food destination. [27] found a brand preference of snack food mediated between product perceived value and purchase intention. If preference has a direct and positive effect on purchase and repurchase intention, this study can propose a relationship between destination food preference and destination food consumption intention of tourist. This study proposes the following hypotheses

H7: Preference for destination foods has a positive effect on revisit intention to eat destination foods.

In recent researches, the perceived value is considered as a key factor that influencing repurchase intentions [1]. Furthermore, many researchers suggested that behavioral intention is based on customer perceived value, and they found that customer perceived value is a basic element of behavioral intention in tourism area [37]. In the research of
[37], the relationship among perceived value and travel intention estimated by the tourists who visit food and drinkthemed events and festivals in Hong Kong. The results showed that there is a relationship between food destination perceived value and revisit intention of tourist. Thus, it is proposed that:

H8: Customer perceived value is a positive effect on revisit intention to eat destination foods.

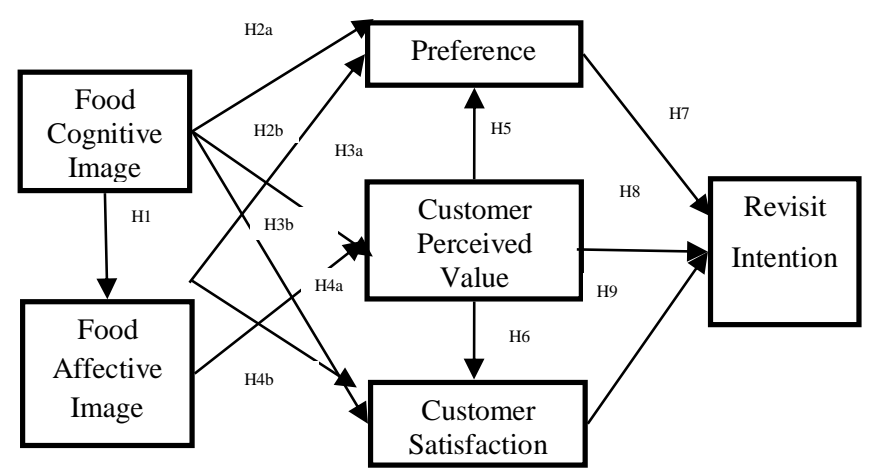

Fig. 1. Conceptual framework.

\section{STUDY 1}

\section{A. Methodology}

Firstly, the purpose of this research paper was to define traveler's Destination Food Image factor comprehension. After reviewing the related literatures that describe "Destination image" as well as the relationship between Destination Image and Social Network, a thematic content analysis was conducted to analysis reviews of travelers on Tripadvisor.

Content analysis is used to analyze the comments of visitor on websites. To ensure reability of measurement result, the development of specific coding categories before content analysis should be design. This study uses a combination of the two main coding categories were identified before conducting the analysis. In order to maintain consistency, the coding process was based on framework of [4] that there is no need for a more detailed classification of the three destination image components (e.g. to differentiate between tourism and general infrastructure in the case of the cognitive component).

\section{B. Data Collection}

According to [18], the influence of e word-of-mouth on decision making process. The main purpose of this paper to indentify assessments of traveler about tour in Ho Chi Minh and the most problem that travelers are interesting in though the TripAdvisor.

We gathered data from "Sai Gon street eats" on TripAdvisor website. To collect the data, we visited the homepage of TripAdvisor website to reach the hot tourism topic that most shared and commented. Firstly, I used " Ho Chi Minh City" as main keyword. Secondly, I choose the topic that ranked in top ten topic. Finally, the study choose the keyword "Sai Gon street eats" that have first ranking in "Atraction Type" section with total 587 reviews. Specifically, the data is collected in 6 months from the early of January, 2018 to the end of July, 2018. The final dataset includes of 73 samples evaluted on that time. For this research, the data analysed by using thematic content analysis that based on two 
factors: food affective image, food cognitive image. To get the result, user's comments are evaluted base on specific words expressing feelings or associations of visitors. These main categories were listed in Table I.

TABLE I: CATEGORIES OF CONTENT FOOD DESTINATION IMAGE ON TRIPADVISOR.COM

\begin{tabular}{|c|c|c|}
\hline Main category & Sub-category & $\begin{array}{l}\text { Example items of } \\
\text { content }\end{array}$ \\
\hline \multirow[t]{5}{*}{$\begin{array}{l}\text { Cognitive } \\
\text { Images }\end{array}$} & $\begin{array}{l}\text { Quality } \\
\text { accommodation }\end{array}$ & $\begin{array}{l}\text { High quality, bad } \\
\text { place }\end{array}$ \\
\hline & $\begin{array}{lll}\text { Good value for } \\
\text { money }\end{array}$ & $\begin{array}{l}\text { Cheap, } \\
\text { expensive, } \\
\text { reasonable }\end{array}$ \\
\hline & Safe place & Clear, safe \\
\hline & Atractive foods & $\begin{array}{l}\text { Delicious, } \\
\text { amazing food }\end{array}$ \\
\hline & Pleasant destination & $\begin{array}{l}\text { Make friend, } \\
\text { friendly }\end{array}$ \\
\hline \multirow[t]{3}{*}{$\begin{array}{l}\text { Affective } \\
\text { Images }\end{array}$} & $\begin{array}{l}\text { A lot of cultural } \\
\text { attractions }\end{array}$ & $\begin{array}{l}\text { Fantastic, love } \\
\text { Vietnamese food }\end{array}$ \\
\hline & $\begin{array}{l}\text { Interesting cultural } \\
\text { activities }\end{array}$ & $\begin{array}{l}\text { Worth to see, } \\
\text { unforgettable }\end{array}$ \\
\hline & $\begin{array}{l}\text { Nice to learn about } \\
\text { local customs }\end{array}$ & $\begin{array}{l}\text { Experience local } \\
\text { life, explore a } \\
\text { culture through } \\
\text { its food }\end{array}$ \\
\hline
\end{tabular}

\section{Data Analyze}

The number of comments of reviewers was quantified based on a qualitative assessment according to destination food image (cognitive and affective image). On this basis, these comments have been classified into two categories: positive comments and negative comments [4]. In total 73 reviews, 156 items related to food destination image were found. Therefore, the average items (mean score: 2.13) were mentioned of each review more than two destination food image traits. In all, $53.8 \%$ of the references mentioned the cognitive food image and $46.2 \%$ references relate to the affective food image. Although it is not equally accurate with regard to references distribution, we detected no significant differences between cognitive and affective with regard to destination food image. To exploring the attitude of reviewer into food image, the next step conducted devide references base on positive and negative comments. The finding reveals that $74.3 \%$ positive evalutions with 68 reviews refer to cognitive food image and 48 reviews refer to affective food image (Fig.2).

\section{Affective Food Image \\ Cognitive Food Image

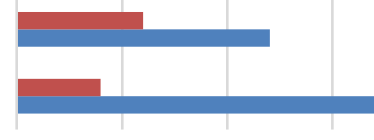 \\ $0 \quad 20 \quad 40 \quad 60$ \\ 80 \\ negative comments $\quad$ Positve comments}

Fig. 2. Negative and positive comments about the two image components.

\section{STUDY 2}

\section{A. Sample and procedure}

Data of this study were collected using a convinient sampling. Then the survey generated on the website https://docs.google.com was sent directly as the invitation to foreign tourists via email and social network such as Facebook or some tourism discuss forums facilitates design procedure as I can spread the form out to people who get involved with this survey. A pilot study was first conducted on 50 tourists on Mekong Delta trip of Sinh café to ensure the validity and reliability of the measurement tools. A series of Cronbach's a tests were carried out to test internal consistency of the constructs. The result indicated that all of the Cronbach a scores were higher than the recommended .70 level, suggesting a good reliability. Afterwards, the finalized survey instrument was used to collect data during the month of February, 2018. A total of 285 responses were collected.

\section{B. Measurements}

Questionnaire items were adapted from previous researches of [22], [39], [24] and [32]. The first part of questionaire was designed to measure demographic information of respondents which included gender, age group, marital status, education level, and average income. Descriptive statistics employing frequency and mean were used. Frequency was first computed to examine demographic and behavioral characteristics of the respondents. The mean score of the 34 attributes were ranked. The second part was aimed at identifying personal information that relates to respondents such as frequency of dining when they travel, the reason for going to travel, information sources of respondents about the restaurant and purpose of dining when they travel. A frequency and percentage data analysis was conducted in these sections. The last part was designed to identify the importance of seven components: food image, food satisfaction, customer perceived value and revisit intention. In this part, the factors used in measuring the satisfaction level and opinions of the customers were generated by previous researchers. The respondents were asked to rate on a seven point Likert scale, ranging from 1 point for "Strongly disagree", 2 points for "Disagree", 3 points for "Moderately disagree", 4 points for "No opinion", 5 points for "Moderately disagree", 6 points for "Agree" and 7 points for "Strongly agree".

\section{Structural equation modelling}

To perform the structural relationships for a conceptual framework, SEM analysis is preferred in tourism and hospitality researches [31]. PLS path-modelling approach that is a variance-based SEM (VB-SEM) attracts remarkable attention for researcher in marketing and consumer behavior studies. VB-SEM including PLS is more suitable for explaining complex relationships based on a component construct concept rather than co-variation between constructs. Furthermore, PLS does not required assumptions such as normality of data distributions and sample size and it is an advantage when the primary concern of the analysis is the prediction originated or prediction accuracy. It is appropriate to perform PSL, as several latent constructs that are circuitously measured by several indicators could be analyzed as confirmatory analysis [15]. PLS is also effective, as its methodological procedure allows researchers to measure heterogeneity within path modelling. [8] 
recommend the two-stage approach. First, the assessment of measurement model, and second, the structural model evaluation followed by previous studies. Therefore, PLSSEM is performed using Smart PLS3 software to empirically test the structural model.

\section{Results}

\section{Respondents profile}

The prequency analysis indicated that $60.5 \%$ respondents were male, $37.3 \%$ between the ages of 25-31. About $52.8 \%$ and $42.9 \%$ of them, respectively, were single and married. Besides, the percentage of respondents who have average income higher than 400 USD is $44.7 \%$. The answer to the question about the prequency of eating Vietnamese food in their trip: $36.1 \%$ regularly, 30.9\% 5-7 times, $18.8 \%$ 3-4 times. $14.2 \%$ seldom. The most purpose of eating Vietnamese food was try local cusine $85 \%$ and the most tourists found information resource of Vietnamese food on internet $73.4 \%$.

\section{Construct reliability and validity}

Reliability is an evaluation of the degree of consistency between multiple measurements of variable and the basic structure of the data was examined by using factor analysis. When the outer loading was $<0.50$, the items have to be deleted and factor loading higher than 0.5-0.6, the coefficient (Cronbach's alpha) accesses the internal consistency of each variable. Table 4-2 shows result of reliability test, the Cronbach's alpha values are higher than 0.7 . It indicates that a high reliability of factors. We can conclude that the data of this survey is reliable and suitable with the general criteria after exclude unsuitable items. The coefficient of determination $\left(\mathrm{R}^{2}\right)$ for the six endogenous latent variables are as follows: 0.580 for food cognitive image, 0.267 for food affective image, 0.696 for preference, 0.497 customer perceived value, 0.529 for customer satisfaction, and 0.382 for revisit intention.), these $\mathrm{R}^{2}$ coefficients are considered to be substantial on moderate The AVEs of the constructs are ranged from 0.696 to 0.845 , greater convergent criterion of the measurements is 0.5 . It confirms satisfactory indicator reliability and convergent validity of the research constructs.

TABLE 2: EVALUATION OF THE MEASUREMENT MODEL

\begin{tabular}{|c|c|c|c|c|c|}
\hline Construct & AVE & CR & $\begin{array}{c}\text { Cronbach's } \\
\text { Alpha }(\alpha)\end{array}$ & $\mathrm{R}^{2}$ \\
\hline $\begin{array}{c}\text { Food cognitive } \\
\text { image }\end{array}$ & & 0.841 & 0.913 & 0.818 & 0.580 \\
\hline $\begin{array}{c}\text { Food affective } \\
\text { image }\end{array}$ & & 0.704 & 0.943 & 0.929 & 0.267 \\
\hline Preference & & 0.725 & 0.646 & 0.713 & 0.696 \\
\hline $\begin{array}{c}\text { Customer } \\
\text { perceived value }\end{array}$ & 0.845 & 0.910 & 0.817 & 0.497 \\
\hline $\begin{array}{c}\text { Customer } \\
\text { satisfaction }\end{array}$ & & 0.701 & 0.550 & 0.697 & 0.529 \\
\hline $\begin{array}{c}\text { Revisit } \\
\text { intention }\end{array}$ & 0.696 & 0.873 & 0.785 & 0.382 \\
\hline
\end{tabular}

Note: * i.e. Formative index cannot calculate CR and AVE.

Table 3 provides the analysis hypothesis result. By using the boot-strapping approach in PLS-SEM, the t-value, pvalue and weights of each dimension were determined. Based on results, the values confirm that 13 hypotheses are significantly by $\mathrm{p}<0.05$ and $\mathrm{t}$-value $>1.96$ with nine hypotheses are positive support and four hypotheses are negative support. However, hypothesis 6 is rejected by $p>0.1$ and t-value <1.96. Hypothesis 1 predicts a positive relationship between cognitive image of destination foods and affective image of destination foods was significant at $p$ $=.000$. For the relationships between cognitive image, affective image of destination foods and preference for destination foods, customer perceived value, customer satisfaction $(\mathrm{H} 2, \mathrm{H} 3, \mathrm{H} 4)$ are accepted by p- value less than 0.05 which indicated that the image of destination foods has effect to preferences, perceived value and satisfaction of tourists in post-travel in culinary destination. Nevertheless, the affective food destination image has negative effect to tourist preference. Hypothesis 5, which predicts a positive relationship between relationship customer perceived value and preference was accepted at $\mathrm{p}=.001$, and the relationship between customer perceived value and customer satisfaction in culinary destination (H6) was rejected. The estimates of the standardized coefficients indicated that the linkage between preference, customer perceived value and customer satisfaction with of destination revisit intention of tourists were significant at $\mathrm{p}$-value less than 0.01 .

TABLE 3: PATH COEFFICIENTS AND RESULTS OF HYPOTHESES TESTS

\begin{tabular}{|c|c|c|c|c|c|c|}
\hline $\begin{array}{l}\text { Origina } \\
\text { sample } \\
(\mathrm{O})\end{array}$ & $\begin{array}{c}\text { Sample } \\
\text { Mean } \\
(\mathrm{M})\end{array}$ & $\begin{array}{c}\text { Standard } \\
\text { Deviation } \\
(\text { STDEV) }\end{array}$ & $\mathrm{T}$ & $\mathrm{P}$ & $\begin{array}{c}\text { Accept/Rej } \\
\text { ect and } \\
\text { significance }\end{array}$ & $\begin{array}{c}\text { Hy } \\
\mathrm{p} .\end{array}$ \\
\hline 0.509 & 0.501 & 0.077 & 6.623 & 0.000 & Accepted & 1 \\
\hline 0.515 & 0.532 & 0.071 & 7.250 & 0.000 & Accepted & $2 \mathrm{a}$ \\
\hline-0.522 & -0.516 & 0.035 & 14.82 & 0.000 & Accepted & $2 \mathrm{~b}$ \\
\hline 0.790 & 0.779 & 0.043 & 5.525 & 0.000 & Accepted & $3 \mathrm{a}$ \\
\hline 0.175 & 0.184 & 0.010 & 3.992 & 0.012 & Accepted & $3 \mathrm{~b}$ \\
\hline 0.890 & 0.891 & 0.065 & 13.67 & 0.000 & Accepted & $4 \mathrm{a}$ \\
\hline 0.595 & 0.592 & 0.048 & 12.34 & 0.000 & Accepted & $4 \mathrm{~b}$ \\
\hline-0.154 & -0.163 & 0.063 & 2.437 & 0.015 & Accepted & 5 \\
\hline 0.250 & 0.246 & 0.064 & 3.902 & 0.000 & Accepted & 6 \\
\hline 0.325 & 0.331 & 0.033 & 10.00 & 0.000 & Accepted & 7 \\
\hline-0.062 & -0.057 & 0.071 & 0.883 & 0.377 & Rejected & 8 \\
\hline 0.276 & 0.278 & 0.091 & 3.021 & 0.003 & Accepted & 9 \\
\hline
\end{tabular}

\section{CONCLUSIONS}

By use qualitative decriptive assessment, study 1 analyzed destination food image in Ho Chi Minh city by two levels. Firstly, the comments of tourists on app TripAdvisor classified into two components: cognitive image and affective image. Secondly, each particular food destination trait is considered as positive and negative evaluation. Generally, the finding suggest that cognitive food image is more popular in reviewers with $53.8 \%$. The study highlights the role of cognitive destination food image, supporting the demand that the evaluation for positively cognition to the destination is higher than positive feelings to the destination such as arousal and pleasure. Nowadays, tourism has become one of the most utility e-commerce system. An increasing number of visitors get more information for their travel plans on the Internet. However, with the explosive growth of the Internet, tourists are usually overwhelmed by the large quantity of travel information. For TripAdivsor users, they can base on online comments to get information quickly and can find useful advice when planning or preparing to attend specific tour program, or destinations, services, hotels, airline tickets (transportation), etc related to the trip. Moreover, study 1 confirmed positive destination food image that evaluated by most of TripAdvisor users $(73.8 \%)$. Thus, how to built 
destination food image, especially cognitive food image is extremely crucial and necessary when Vietnam intend to build an attractive food destination that perceived by tourist.

Moreover, study 2 was conducted to assert the role destination food image into revisit intention for local cuisine. The findings confirmed cognitive food image (cooking methods, safety, quality, attractiveness) has influence to affective food image. Some of cognitive food image components could evaluated by the affective attribute, particularly those that concern with culture, people [32].

Generally, in the model, the influence of cognitive aspects became stronger than affective aspects. In other words, destination knowledge (cognitive factor) of tourists seems be more related to preference, perceived value and satisfaction than pleasant feeling (affective factor). Similarly study 1 , cognitive image has contribute to the most orall destination image, based on the food destination attraction and culinary culture [16], creating the diffirence and destination' competiness.

In this way, the usefulness of overall destination image, in terms of its dual cognitive-affective aspects, becomes clear through the results obtained. However, in the model, cognitive aspects contribute the most to image formation, based on the destinations'different historical, heritage or natural resources [16]. Celebrating successful events can enhance a location's image, consolidating it as a tourist destination or diminishing seasonality by extending the tourist season [28]. Though the results obtained, cognitive food destination images are created positively, the preference, customer peceived value and customer satisfaction are more increase. The finding confirmed similar the previous study that positive relationship between image of food destination and tourist's preference. The impact of destination food image on behavior's tourist, that involve destination preferences [22]. Positive food image is a distinctive feature that influence to tourist's preference for a destination and provide trustworthy source of information for tourist [27]. Nowadays, social media has recently been used to find services and products and influence decision-making processes though reliable information and lively image [43]. Following by Vietnam traditional culinary cognitive image, including safety food, attractiveness of food, food culture also affected essentially to tourist's preference. Not only that, the feeling of tourist has been viewed an essential factor that influence preference and change mind of Vietnamese food destination image before.

This study not only indicated the relationship between the orall food destination image (cognitive image and affective image) and perceived value of tourist but also provides a more but also confirms a more comprehensive understanding of their effect on customer satisfaction, which leads to a higher overall influence on behavioral intentions. Therefore, favorable food destination image building by tourism manager and marketing is crucial. The founder of modern marketing Philip Kotler, keynote speaker at the international conference: "New Marketing for the New Age" asserted that "The kitchen of the world" might be a suitable marketing image for Vietnam. While perceived value was the significant determinant of preference and customer satisfaction, but it was not a significant predictor of revisit intention. Within the culinary tourism context, Vietnam is known as an attractive fine-dining destinations and cheap service in recent years. However, the return rate of tourist to Viet Nam is just $5 \%$, in comparison to neighboring Singapore or Thailand 50\% (Vietnam National Administration of Tourism, 2017). Limited service product and the lack of budget to be spent on tourism promotion, complicated tourist-targeting and "samesame" tours are the causes of one-off destination. The same culinary promotion tour from other countries such as Thailand and Malaysia where have vary culinary activities as street food, local markets, fine dining, and cooking courses. Thus, they are more concerned with the product diversification and service quality improvement, rather than the cost of service. Although the finding show perceived value of tourist no direct effect on revisit intention, however, perceived value has influence satisfaction. This relationship should be further examined to confirm the role of customer satisfaction and revisit intention is a mediating effect.

According to the research results, this study recommends food destination image should concentrate on the positive food destination in marketing campaign to international tourists in Vietnam. Furthermore, tourist behavior to choose a food destination depends on the cognitive food destination image than affective image. Thus, to present variety of food images, [13] recommend that the using promotional tools as websites, social media, guides book, brochures to provide useful information about local food and recommendations fresh and tasty flavors food destinations. On the other side, food service includes tangible and intangible factor. While cognitive image involves only characteristics of perception, affective image consists of emotion. Therefore, destination management should also develop spirit activities such as Vegetarian Festival (Phuket, Thailand) or Dumpling Festival (Hongkong).

Moreover, word-of-mouth and social media have an important role to build destination [36], thus, to maximize the food destination image, marketers should provide detail information of local food, restaurant, price and promotion, etc. Positive food destination image will influence tourist satisfaction and their revisit intentions. Finally, Vietnam government should concentrate on mass tourism by develop mobile in-app that tourists can find images, restaurant, review and comments as the Singapore Tourism Board do and British Tourist Authority do.

\section{LIMITATIONS AND SUGGESTIONS FOR FUTURE RESEARCH}

There are certain limitations in this research. The data collection method is the convenience sample method not represented all international tourist. The investigation design could have more detail in psychographic characteristics such as personality, life styles, as well as, categories of advertisements, etc. The study could not eliminate the impact of measurement error by using indicator. Secondly, the respondents are foreign tourist. Therefore, the future research might consider examining responses from dometic tourist to see whether there are differences between the various races of people and with various appreciations and attitude. To apply traditional food into culinary tourism, further validation from different population is very useful. Finally, future research should to extend the comparison social demographics of tourists in diffirent area. Relationships between local food consumption value and other constructs may vary according to the social demographics of tourists 
(e.g., gender, age, marital status, and income). Future studies need to explore the relationships between tourists'local food consumption value and tourists's demographics from a marketing perspective as the relationships between local food consumption value and other constructs may vary according to the social demographics of tourists (e.g., gender,age, marital status, and income). Future studies need to explore the relationships between tourists' local food consumption value and tourists'demographics from a marketing perspective.

\section{REFERENCES}

[1] Ab Karim, S., \& Chi, C. G. Q. (2010). Culinary tourism as a destination attraction: An empirical examination of destinations' food image. Journal of hospitality marketing \& management, 19(6), 531555 .

[2] Alderighi, M., Bianchi, C., \& Lorenzini, E. (2016). The impact of local food specialities on the decision to (re) visit a tourist destination: Market-expanding or business-stealing? Tourism Management, 57, 323-333.

[3] Allameh, S. M., Khazaei Pool, J., Jaberi, A., Salehzadeh, R., \& Asadi, H. (2015). Factors influencing sport tourists' revisit intentions: The role and effect of destination image, perceived quality, perceived value and satisfaction. Asia Pacific Journal of Marketing and Logistics, 27(2), 191-207.

[4] Björk, P., \& Kauppinen-Räisänen, H. (2016). Local food: a source for destination attraction. International Journal of Contemporary Hospitality Management, 28(1), 177-194.

[5] Chen, C. C., Lai, Y. H. R., Petrick, J. F., \& Lin, Y. H. (2016). Tourism between divided nations: An examination of stereotyping on destination image. Tourism Management, 55, 25-36

[6] Chen, C. F., \& Chen, F. S. (2010). Experience quality, perceived value, satisfaction and behavioral intentions for heritage tourists. Tourism management, 31(1), 29-35.

[7] Chen, C. F., Leask, A., \& Phou, S. (2016). Symbolic, experiential and functional consumptions of heritage tourism destinations: The case of angkor world heritage site, cambodia. International Journal of Tourism Research, 18(6), 602-611.

[8] Chon, K. S. (2015). Traveler destination image modification process and its marketing implications. In Proceedings of the 1990 Academy of Marketing Science (AMS) Annual Conference (pp. 480-482). Springer, Cham.

[9] Cohen, E., \& Avieli, N. (2004). Food in tourism: Attraction and impediment. Annals of tourism Research, 31(4), 755-778.

[10] Crompton, J. L. (1979). Motivations for pleasure vacation. Annals of tourism research, 6(4), 408-424.

[11] Du Rand, G. E., \& Heath, E. R. N. I. E. (2009). Local food as a key element of sustainable tourism competitiveness. Sustainable Tourism in Southern Africa: Local Communities and Natural Resources in Transition, Jarkko Saarinen, 253-268.

[12] Folgado-Fernández, J. A., Hernández-Mogollón, J. M., \& Duarte, P. (2017). Destination image and loyalty development: the impact of tourists' food experiences at gastronomic events. Scandinavian Journal of Hospitality and Tourism, 17(1), 92-110.

[13] Hong, P. T. T., \& Diep, D. K. Q. (2016). The Influence of Branding Management on Business Performance: An Empirical Evidence from Vietnamese Food and Beverage Industry. International Journal of Business Administration, 7(3), 36.

[14] Horng, J. S., \& Hu, M. L. (2009). The creative culinary process: constructing and extending a four-component model. Creativity Research Journal, 21(4), 376-383.

[15] Hosany, S., Ekinci, Y., \& Uysal, M. (2006). Destination image and destination personality: An application of branding theories to tourism places. Journal of business research, 59(5), 638-642.

[16] Hosany, S., Prayag, G., Van Der Veen, R., Huang, S. S., \& Deesilatham, S. (2016). Mediating Effects of Place Attachment and Satisfaction on the Relationship between Tourists' Emotions and Intention to Recommend. Journal of Travel Research, 0047287516678088.

[17] Hui, T. K., Wan, D., \& Ho, A. (2007). Tourists' satisfaction, recommendation and revisiting Singapore. Tourism management, 28(4), 965-975.

[18] Jalilvand, M. R., \& Samiei, N. (2012). The impact of electronic word of mouth on a tourism destination choice: Testing the theory of planned behavior (TPB). Internet Research: Electronic Networking Applications and Policy, 22(5), 591-612.

[19] Kang, J., Jun, J., \& Arendt, S. W. (2015). Understanding customers' healthy food choices at casual dining restaurants: Using the ValueAttitude-Behavior model. International Journal of Hospitality Management, 48, 12-21

[20] Kaura, V., Durga Prasad, C. S., \& Sharma, S. (2015). Service quality, service convenience, price and fairness, customer loyalty, and the mediating role of customer satisfaction. International Journal of Bank Marketing, 33(4), 404-422.

[21] Kazemi, M., Pour, S., Saadat, F., \& Bitaraf, F. (2011). The Effect of Tourist's Mental Image on the Perceived Value of Coastal Cities in the Caspian Sea.

[22] Kim, Y. H., Duncan, J., \& Chung, B. W. (2015). Involvement, satisfaction, perceived value, and revisit intention: A case study of a food festival. Journal of culinary science \& technology, 13(2), 133158 .

[23] Kladou, S., \& Mavragani, E. (2015). Assessing destination image: An online marketing approach and the case of TripAdvisor. Journal of Destination Marketing \& Management, 4(3), 187-193.

[24] Konecnik, M. (2004). Evaluating Slovenia's image as a tourism destination: A self-analysis process towards building a destination brand. Journal of brand management, 11(4), 307-316.

[25] Köster, E. P., \& Mojet, J. (2015). From mood to food and from food to mood: A psychological perspective on the measurement of food-related emotions in consumer research. Food Research International, 76, 180191.

[26] Kim, S. E., Lee, K. Y., Shin, S. I., \& Yang, S. B. (2017). Effects of tourism information quality in social media on destination image formation: The case of Sina Weibo. Information \& Management, 54(6), 687-702.

[27] Lai, M. Y., Khoo-Lattimore, C., \& Wang, Y. (2017). Food and cuisine image in destination branding: Toward a conceptual model. Tourism and Hospitality Research, 1467358417740763.

[28] Lawson, F., \& Baud-Bovy, M. (1977). Tourism and recreation development, a handbook of physical planning. Tourism and recreation development, a handbook of physical planning.

[29] Lee, K. H., \& Scott, N. (2015). Food tourism reviewed using the paradigm funnel approach. Journal of culinary science \& technology, 13(2), 95-115.

[30] Lee, H. J., \& Yun, Z. S. (2015). Consumers' perceptions of organic food attributes and cognitive and affective attitudes as determinants of their purchase intentions toward organic food. Food quality and preference, 39, 259-267.

[31] Lee, J. S., Breiter, D., \& Choi, Y. (2011). Quality of a green destination as perceived by convention attendees: The relationship between greening and competitiveness.

[32] Lin, Y. C., Pearson, T. E., \& Cai, L. A. (2011). Food as a form of destination identity: A tourism destination brand perspective. Tourism and Hospitality Research, 11(1), 30-48.

[33] Muhoho-Minni, P., \& Lubbe, B. A. (2017). The role of the media in constructing a destination image: The Kenya experience. Communicatio, 43(1), 58-79.

[34] Papadimitriou, D., Kaplanidou, K., \& Apostolopoulou, A. (2018). Destination image components and word-of-mouth intentions in urban tourism: A multigroup approach. Journal of Hospitality \& Tourism Research, 42(4), 503-527.

[35] Prayag, G., Van Der Veen, R., Huang, S., \& Hosany, S. (2015) Emotions, Satisfaction, and Place Attachment: A Structural Model.

[36] Quan, S., \& Wang, N. (2004). Towards a structural model of the tourist experience: An illustration from food experiences in tourism. Tourism management, 25(3), 297-305.

[37] Qu, H., Kim, L. H., \& Im, H. H. (2011). A model of destination branding: Integrating the concepts of the branding and destination image. Tourism management, 32(3), 465-476.

[38] San Martín, H., \& Del Bosque, I. A. R. (2008). Exploring the cognitive-affective nature of destination image and the role of psychological factors in its formation. Tourism management, 29(2), 263-277.

[39] Seo, S., Yun, N., \& Kim, O. Y. (2017). Destination food image and intention to eat destination foods: a view from Korea. Current Issues in Tourism, 20(2), 135-156.

[40] Smith, W. W., Li, X. R., Pan, B., Witte, M., \& Doherty, S. T. (2015). Tracking destination image across the trip experience with smartphone technology. Tourism Management, 48, 113-122.

[41] Sohn, H. K., \& Yoon, Y. S. (2016). Verification of Destination Attachment and Moderating Effects in the Relationship Between the Perception of and Satisfaction with Tourism Destinations: A Focus on 
Japanese Tourists. Journal of Travel \& Tourism Marketing, 33(5), 757 769.

[42] Stylos, N., Bellou, V., Andronikidis, A., \& Vassiliadis, C. A. (2017) Linking the dots among destination images, place attachment, and revisit intentions: A study among British and Russian tourists. Tourism Management, 60, 15-29.

[43] Veasna, S., Wu, W. Y., \& Huang, C. H. (2013). The impact of destination source credibility on destination satisfaction: The mediating effects of destination attachment and destination image. Tourism Management, 36, 511-526.

[44] Zeng, B., \& Gerritsen, R. (2014). What do we know about social media in tourism? A review. Tourism Management Perspectives, 10, 27-36.

[45] Zhao, W., \& Ritchie, J. B. (2007). Tourism and poverty alleviation: An integrative research framework. Current Issues in Tourism, 10(2-3), 119-143.

Hsin- Kuang Chi: Associate Professor, Department of Business Administration, Nanhua University, No. 55, Sec. 1, Nanhua Rd., Dalin Township, Chiayi County 62249, Taiwan;

Kuo- Chung Huang: Professor, Department of Business Administration, Nanhua University, No. 55, Sec. 1, Nanhua Rd., Dalin Township, Chiayi County 62249, Taiwan;

Bich Dao Thi Nguyen: Ph. D. student, Department of Business Administration, Nanhua University, No. 55, Sec. 1, Nanhua Rd., Dalin Township, Chiayi County 62249, Taiwan; E-mail: nt bichdao89@yahoo.com.vn

Lecturer, Department of Social Science and Humanities, Ton Duc Thang University, Vietnam. 